\title{
ОСОБЛИВОСТІ ВИКОРИСТАННЯ МЕТОДУ ПРОСКТІВ ПІД ЧАС ВИКЛАДАННЯ ПЕДАГОГІЧНИХ ДИСЦИПЛІН
}

\author{
Онищенко Н. П. \\ доктор педагогічних наук, доцент, \\ професор кафедри загальної педагогіки і педагогіки вищої школи \\ Університет Григорія Сковороди в Переяславі \\ вул. Сухомлинського, 30, Переяслав, Київська область, Україна \\ orcid.org/0000-0001-7794-8949 \\ Onischenkon@gmail.com
}

\author{
Ключові слова: завдання \\ проєктної технології, \\ параметри зовнішньої \\ оцінки проєкту, класифікація \\ проєктів, дослідницькі \\ проєкти, творчі проєкти, \\ інформаційні проєкти, \\ практико-орієнтовані \\ проєкти, прикладні проєкти, \\ телекомунікаційні проєкти, \\ ігрові проєкти.
}

\begin{abstract}
У статті розкрито особливості використання методу проєктів під час викладання педагогічних дисциплін. Визначено, що сутність проєктної технології полягає у застосуванні цілісної системи засобів, що передбачає системне і послідовне моделювання розв'язання проблемних ситуацій, які вимагають від учасників освітнього процесу значних пошукових зусиль, їхньої творчої активності, дослідження й розробки оптимальних шляхів розв'язання проєктів, їх публічного захисту й аналізу підсумків упровадження. Доведено, що метою проєктування освітнього процесу $\epsilon$ створення викладачем таких умов під час його проходження, за яких результатом проєктування виступає індивідуальний досвід проєктної діяльності кожного конкретного студента. Виділено основні вимоги до використання проєктної технології: наявність конкретного завдання, що потребує інтегрованих знань, наявності певних умінь і навичок, дослідницького пошуку з метою розв'язання значущої проблеми в дослідницькому, творчому плані; теоретична і практична пізнавальна значущість результатів, передбачуваних у процесі виконання певних завдань; індивідуальна і групова самостійна діяльність студентів щодо розв'язання певних проєктів; поетапне структурування змістової частини проєкту з виділенням результатів конкретних його частин; застосування дослідницьких методів (аналізу, синтезу, підведення підсумків, коректування, узагальнення висновків тощо). У статті розкрито особливості різних типів проєктів, які можна використовувати під час викладання педагогічних дисциплін, а саме: дослідницьких, творчих, інформаційних, практико-орієнтованих, прикладних, телекомунікаційних, ігрових, рольових. Виділено параметри зовнішньої оцінки проєкту та вимоги до структурування проєкту. Зроблено висновок, що використання проєктних технологій у вищій школі розвиває пізнавальну сферу та особистісні якості студентів, перетворює викладача із носія готових знань на організатора творчої діяльності майбутніх учителів. Зазначено, що проєктні технології вчать студентів самостійно шукати шляхи вирішення різних проблем, що мають теоретичне і практичне значення.
\end{abstract}




\title{
FEATURES OF USING THE PROJECT METHOD WHILE TEACHING PEDAGOGICAL DISCIPLINES
}

\author{
Onyshchenko N. P. \\ Doctor of Pedagogical Sciences, Associate Professor, \\ Professor at the Department of General Pedagogy and Higher School Pedagogy \\ Hryhoriy Skovoroda University in Pereyaslav \\ Sukhomlynsky str., 30, Pereyaslav, Kyiv region, Ukraine \\ orcid.org/0000-0001-7794-8949 \\ Onischenkon@gmail.com
}

\begin{abstract}
Key words: tasks of project technology, parameters of external project evaluation, classification of projects, research projects, creative projects, information projects, practice-oriented projects, applied projects, telecommunication projects, game projects.
\end{abstract}

\begin{abstract}
The article reveals the peculiarities of the application of the project method in the teaching of pedagogical disciplines. It is determined that the essence of project technology is to use a holistic system of tools that provides systematic and consistent modeling of problem solving, which require participants in the educational process significant research efforts, their creative activity, research and development of optimal ways to solve projects, their public protection and analysis of the results of implementation. It is proved that the purpose of designing the educational process is to create such conditions for the teacher during its passage, according to which the result of the design is the individual experience of project activities of each student. The main requirements for the use of project technology are identified: the presence of a specific task that requires integrated knowledge, the availability of certain skills and abilities, research search in order to solve a significant problem in research, creative terms; theoretical and practical cognitive significance of the results expected in the process of performing certain tasks; individual and group independent activity of students on solving certain projects; gradual structuring of the content of the project with the selection of the results of its specific parts; application of research methods (analysis, synthesis, summing up, correction, generalization of conclusions, etc.). The article reveals the features of different types of projects that can be used in the teaching of pedagogical disciplines, namely: research, creative, informational, practice-oriented, applied, telecommunications, games, role-playing. The parameters of the external evaluation of the project and the requirements for structuring the project are highlighted. It is concluded that the use of project technologies in higher education develops the cognitive sphere and personal qualities of students, turns the teacher from a carrier of ready-made knowledge into an organizer of creative activities of future teachers. It is noted that project technologies teach students to independently look for ways to solve various problems that have theoretical and practical significance.
\end{abstract}

Постановка проблеми. Важливою метою сучасної державної політики підготовки вчителя до практичної діяльності є оновлення змісту підготовки, сприяння підвищенню професійного рівня вчителів та їхньої готовності змінювати організацію освітнього процесу відповідно до наявних демократичних цінностей, сучасних наукових досягнень. Згідно із Законами України «Про вищу освіту» (2014), «Про повну загальну середню освіту» (2020), Стратегією розвитку вищої освіти в Україні на 2021-2031 роки відбувається активне залучення до освітнього процесу інноваційних технологій. Розв'язання цієї проблеми неможливе без використання у педагогічному процесі вищої школи інноваційних технологій, які стимулюють прояви творчості, зокрема проєктних технологій. Визначною рисою сучасності стає формування проєктної культури вчителя як організатора та ініціатора проєктно-технологічної і навчально-виховної діяльності.

Сучасний аналіз психолого-педагогічних досліджень засвідчує високий ступінь розробленості проблеми проєктування та використання цієї проблематики у різних галузях науки. Філо- 
софсько-педагогічні аспекти проєктної технології розглядалися в роботах Дж. Джонса, Дж. Дьюї, У. Кілпатрика, Є. Коллінгса, Л. Левіна та ін. Проблеми становлення проєктної культури висвітлено у працях Г. Батищева, М. Бахтіна, В. Безпалько, Л. Виготського, М .Кагана, В. Монахова, Є.Полат, С. Шацького, Н. Яковлевої та ін. Окремі питання підготовки вчителя до організації проєктної діяльності знайшли своє відображення у дослідженнях Ю. Веселової, М. Пелагейченко, С. Ізбаш, Е. Кручай, О. Ожерельєвої, Н. Торлопової, Ю. Фильчакової та ін. Але ці праці здебільшого пов'язані 3 розв'язанням проблем проєктної діяльності у сфері різних шкільних предметів, досить обмежено висвітлено проблему підготовки студентів до використання проєктних технологій під час вивчення педагогічних дисциплін.

Проєктна технологія у тісному зв'язку з реальною життєвою практикою сприяє ефективному здобуттю знань, формуванню і розвитку специфічних умінь та навичок завдяки системній організації проблемно-орієнтованого пошуку. У процесі застосування проєктних технологій під час викладання педагогічних дисциплін відбувається системне і послідовне моделювання проблемних ситуацій, що потребують від учасників освітнього процесу їх розв'язання, пошукових зусиль на дослідження й розробку оптимальних шляхів створення різних проєктів, їх захист і аналіз отриманих результатів.

Meта статmi - розкриття особливостей використання методу проєктів під час викладання педагогічних дисциплін.

Виклад основного матеріалу дослідження. Сучасна педагогіка характеризується переосмисленням і зміною усталених традицій та стереотипів, тому у наш час проєктування стає інтегрованим компонентом системи середньої і вищої освіти. За Є. Полат проєктна технологія передбачає певну сукупність навчально-пізнавальних прийомів, що дозволяють вирішити певну проблему під час самостійних дій із обов'язковою презентацією результатів. Якщо говорити про метод проєктів як педагогічну технологію, то вона передбачає сукупність дослідницьких проблемних методів, творчих за своєю діяльністю [1]. Тематика повинна бути різноманітною і розвивати творче мислення, навички дослідження, уміння інтегрувати знання. Більшість науковців схильна розглядати метод проєктів як технологічну діяльність (О. Ільяшева, В. Копилова, Н. Пахомова, О. Рибіна, I. Соловйова, І. Чечель та ін.). І. Бем та Й. Шнайдер - до продуктивних методів навчання [2, с. 16]. Основний принцип методу проєктів - це опора на інтереси сьогодення, що повинно бути вихідним принципом навчання. Робота над проєктом, як зазначає О. Пєхота, це практика особи- стісно орієнтованого навчання на основі вільного вибору з урахуванням пізнавальних інтересів [3].

Слово «проєкт» у перекладі з латинської мови означає «кинутий вперед». Це цільовий акт діяльності, в основі якого - інтерес студента. У сучасному розумінні проєкт - це будь-який задум, що має мету, термін та конкретні кроки реалізації. Робота над проєктом передбачає використання практики особистісно орієнтованого навчання у процесі індивідуальної праці студентів, на основі ïх вільного вибору й урахування особистісних інтересів. Значення методу проєктів для студентів обумовлюється розвитком їх умінь усвідомлювати певні завдання, намічати послідовність дій щодо їх реалізації, проявляти творчість й активність. Для викладача - це прагнення знайти розумний баланс між академічними і прагматичними знаннями, уміннями та навичками. У першу чергу проєктування орієнтоване на самостійну діяльність студентів - індивідуальну, парну або групову, яку вони виконують за певний період часу, отже, метод проєктів учить студентів груповій взаємодії.

Технологія проєктування передбачає розв'язання студентом або групою студентів конкретної проблеми, що передбачає, з одного боку, використання різноманітних методів, засобів навчання або виховання, а з іншого - інтегрування знань, умінь із різних галузей науки, техніки, творчості. Основною вимогою до результатів виконання проєктів повинна бути їх вагомість: у дослідженні теоретичних проблем - конкретні висновки i рішення, у дослідженні практичних проблем конкретний результат, готовий до впровадження. Проєктна технологія передбачає використання викладачем дослідницьких, пошукових, творчих методів, прийомів навчання.

Сутність проєктної технології полягає у застосуванні цілісної системи засобів (змісту, методів, прийомів тощо), що передбачає системне і послідовне моделювання розв'язання проблемних ситуацій, які вимагають від учасників освітнього процесу значних пошукових зусиль, їх творчої активності, дослідження й розробки оптимальних шляхів розв'язання проєктів, їх публічного захисту й аналізу підсумків упровадження.

Метою проєктування освітнього процесу $\epsilon$ створення викладачем таких умов під час його проходження, за яких результатом проєктування виступає індивідуальний досвід проєктної діяльності кожного конкретного студента. Оскільки проєктне навчання розвивається у продуктивній діяльності, то воно розширює сферу суб'єктивності особистості в процесі власного самовизначення, творчості і визначеної конкретної участі. У процесі використання технології проєктування під час викладання педагогічних дисциплін 
вирішується ціла низка різнорівневих дидактичних, виховних і розвивальних завдань, а саме: формується вміння самостійно конструювати свої знання, розвиваються пізнавальні навички студентів, вміння орієнтуватися в інформаційному просторі, активно розвивається критичне мислення, комунікативні вміння тощо.

Основні завдання проєктної технології: вчити проблематизації (розгляду проблемного поля та виділенню підпроблем, формулюванню провідної проблеми та постановці завдань); навчити здобувати знання самостійно, вміти застосовувати їх на практиці у різних ситуаціях; сприяти формуванню у студентів комунікативних навичок, тобто здатності працювати у різноманітних групах, виконувати різні соціальні ролі (виконавця, посередника, лідера-управлінця тощо); розширювати коло спілкування студентів, навчити проводити презентації у різних формах, сприймати різні точки зору на одну проблему; розвивати у студентів уміння пошуку та відбору актуальної інформації, вміти їі аналізувати, висувати гіпотези, узагальнювати.

Основні вимоги до використання проєктної технології: наявність конкретного завдання, що потребує інтегрованих знань, наявності певних умінь $\mathrm{i}$ навичок, дослідницького пошуку 3 метою розв'язання значущої проблеми в дослідницькому, творчому плані; теоретична i практична пізнавальна значущість результатів, передбачуваних у процесі виконання певних завдань; індивідуальна і групова самостійна діяльність студентів щодо розв'язання певних проєктів; поетапне структурування змістової частини проєкту з виділенням результатів конкретних його частин; застосування дослідницьких методів (аналізу, синтезу, підведення підсумків, коректування, узагальнення висновків тощо).

У процесі використання проєктних технологій під час вивчення педагогічних дисциплін студенти повинні набути такі вміння та навички: рефлексивні (осмислення завдань), пошукові (дослідницькі) - вміння самостійно генерувати ідеї, самостійний пошук інформації, формулювання запитань до викладача, вміння знаходити декілька варіантів вирішення проблеми, висунення власної гіпотези, встановлення причинно-наслідкових зв'язків; комунікативні (вміння вступати в діалог, ведення дискуciï, захист власної точки зору, вміння домовлятись i знаходити компроміс, ітерв'ювання, усне опитування, керування голосом тощо); презентаційні (навички монологічного мовлення, витримка під час публічного виступу, артистичні вміння, використання різних засобів наочності); навички оціночної самостійності (адекватне оцінювання своєї роботи та робіт інших студентів, пошук недоліків, визначення конструктивних побажань, зауважень); уміння та навички співпраці (колективне планування роботи групи, взаємодія 3 різними членами групи, надання взаємодопомоги, навички ділового партнерського спілкування тощо).

Проєкти можуть бути на різну тематику, запропоновану викладачами з урахуванням навчальної ситуації зі свого предмета, інтересів та здібностей студентів. Тему проєкту можуть запропонувати і самі студенти. Результати проєктів повинні бути відповідно оформлені (відеофільм, альбом, бортжурнал, комп'ютерна газета, альманах тощо).

3 огляду на різні підходи до класифікації проєктів їх розрізняють за цілим рядом параметрів: за складом учасників: індивідуальні, колективні (парні, групові); за характером партнерських взаємодій між учасниками: кооперативні, змагальні, конкурсні; за рівнем реалізації міжпредметних зв'язків: монопредметні; міжпредметні; надпредметні; за характером координації проєкту: безпосередні; приховані; за тривалістю: короткі; середньої тривалості; тривалі; за метою і характером проєктної діяльності: дослідницькі, творчі, ігрові, інформаційні, практико-орієнтовані, телекомунікаційні, ознайомлювальні, пригодницькі, мистецькі, науково-пошукові, конструкційні тощо [4]. Отже, проєктні технології класифікують за різними ознаками, що дає можливість виокремити різні їх види.

У контексті нашого дослідження розглянемо різні типи проєктів, які можна використовувати під час викладання педагогічних дисциплін.

Дослідницькі проєкти - проєкти, які передбачають наявність чіткої структури, визначеної мети, актуальності дослідження, значення, методів дослідження (у тому числі експериментальних і дослідницьких, а також опрацювання результатів). Ці проєкти сприяють логіці дослідження, їхня структура наближена або така ж, як у наукових дослідженнях. Цей тип проєктів включає: актуальність теми дослідження; формулювання проблеми дослідження, його предмета і об'єкта; визначення завдань; визначення методів, джерел інформації; вибір методології, обгрунтування гіпотези; визначення плану й шляхів вирішення проблеми; обговорення результатів проєктів у процесі групової діяльності; оформлення висновків; узагальнення результатів досліджень; визначення нових проблем для подальшого розвитку дослідження.

Творчі проєкти передбачають різні нестандартні підходи до розв'язання проблеми, що не мають детально розробленої структури спільної діяльності ii учасників. Цей вид проєктів розвивається і підпорядковується прикінцевому результату, узгоджується із прийнятою групою логікою спільної діяльності, інтересами учасників проєкту. Творчі проєкти мають певні заплановані результати i узгоджені форми їх представлення (вечори, свята, журнали різних видів, колективні колажи, відеофільми, вебінари тощо). Оформлення результатів творчого проєкту вимагають чітко продуманої їх структури, 
певних інновацій у створенні послідовності дій та їх інтерпретації тощо.

Рольові проєкти - це проєкти, в яких їх характер і зміст коригуються у визначених для учасників ролях. Структура цих проєктів має узагальнений вигляд i залишається відкритою до завершення роботи над проєктом (вигадані герої, літературні персонажі, імітують соціальні або ділові відносини). У цих проєктах переважає рольова гра, хоча ступінь творчості в них $є$ дуже високою. Результати цих проєктів подаються або на початку виконання проєкту, або після його завершення.

Ігрові проєкти передбачають ігрову взаємодію учасників, що обирають різні ролі, обумовлені характером і змістом проєкту. Ігрові проєкти імітують соціальні й ділові стосунки літературних персонажів, реальних людей, героїв кінофільмів і мультфільмів тощо, які ускладнюються вигаданими учасниками ситуаціями. Ступінь творчості студентів - високий, домінуючим видом діяльності є гра.

Інформаиійні проєкти пов'язані зі збором інформації про певні явища або якийсь об'єкт. Інформація, зазвичай, збирається членами мікрогрупи 3 конкретно визначених питань. Із знайденою інформацією ознайомлюються усі учасники проєкту, які аналізують і узагальнюють певні факти та різний матеріал. Інформаційні проєкти вимагають добре продуманої структури проведення й іiї систематичної корекції у процесі виконання різних етапів робіт (визначення мети; аналіз різних джерел інформації (засобів масової інформації, законодавчих баз даних, методичних видань тощо); обробка інформації (узагальнення, зіставлення, висновки); оформлення результатів (у вигляді реферату, доповіді, статті, есе тощо); презентація проєкту (з використанням електронних носіїв тощо). Інформаційні проєкти ще називають ознайомлювально-орієнтовними, що часто інтегруються у дослідницькі проєкти і стають їх складовою (модулем).

Практико-орієнтовані проєкти спрямовані на отримання практичного результату діяльності iї учасників, що орієнтований на соціальні інтереси (складання документів, програм; розробка навчально-методичних рекомендацій, сценарію виховних заходів тощо). Особливо важливими в реалізації такого типу проєктів $є$ організація координаційної роботи у вигляді поетапних обговорень та презентацій одержаних результатів і можливих засобів їх упровадження у практику. Проєкт потребує надання практичних завдань усім учасникам із визначенням функцій кожного з них.

Прикладні проєкти - мають певну специфіку, що визначає результат діяльності ї учасників на самому початку та обов'язково орієнтовані на соціальні інтереси учасників, співзвучні зі практично-орієнтованими проєктами. У цьому проєкті важлива роль відводиться організації координацій- ної роботи у процесі поетапних обговорень, коректуванні спільних та індивідуальних зусиль, обробці отриманих результатів і пропозицій щодо впровадження їх у практику, зовнішньої та систематичної оцінки проєкту. Сценарій такого типу проєктів для діяльності іiі учасників передбачає визначення їх функцій і участі кожного учасника в оформленні кінцевого результату.

Телекомунікаиійні проєкти - це спільна творча або ігрова діяльність студентів-партнерів, організована на основі комп'ютерної телекомунікації, що має спільну мету (дослідження певної проблеми), узгоджені методи, способи діяльності й спрямована на досягнення спільного результату. Телекомунікаційний проєкт виконується із застосуванням таких комп'ютерних засобів як електронна пошта і мережа Web-сайтів. Останнім часом популярності набувають так звані Інтернет-проєкти, які спрямовані на підвищення рівня мовленнєвих навичок студентів та допомагають навчитися отримувати значний обсяг країнознавчої інформації. Найбільш поширеними $\epsilon$ два види таких проєктів: www-проєкти та E-mail проекти, планування, проведення та результати яких суттєво відрізняються між собою. Www-проєкти спрямовані на розвиток умінь знаходити інформацію в Інтернеті та презентувати результати власного пошуку, a E-mail проєкти підвищують рівень писемної комунікації [5, с. 115-124].

Під час викладання педагогічних дисциплін найчастіше доводиться мати справу зі змішаними типами проєктів. Важливим аспектом виконання цих проєктів є організація зовнішньої оцінки їх виконання, що дозволяє підвищити їх ефективність, усувати певні труднощі у виконанні, вносити вчасну корекцію у зміст і структуру проєктів. В ігрових проєктах, які мають характер змагання, може використовуватися бальна система оцінювання. Проєкт має певні етапи реалізації: організаційний, підготовчий, проєктна робота, оформлювальний, презентація проєкту, підведення підсумків. Уміння користуватися проєктною технологією є показником високої кваліфікації викладача, його інноваційного мислення, орієнтації на особистісний і професійний розвиток студентів у процесі навчання. Під час організації проєктування освітнього процесу викладач виконує такі функції: допомагає студентам у пошуку джерел інформації у роботі над проєктом; координує весь процес роботи над проєктом; підтримує і заохочує студентів; підтримує неперервний рух студентів у роботі над проєктом.

Зазначимо, що викладач повинен вміти допомогти студенту, не виконуючи роботи замість нього, також він повинен не лише добре знати свій предмет, а й бути компетентним в інших галузях науки, бачити точки їх зіткнення. Викладач повинен добре знати своїх студентів, їхні можливості, інтереси, бажання. Психологічна грамотність і компетентність 
викладача важливі для організації проєктної діяльності студентів під час викладання педагогічних дисциплін. Викладач повинен бути комунікабельним, толерантним, проявляти емпатію до інших. Особливу роль відіграють його креативні здібності, творчий потенціал, досвід творчої діяльності, особливо в процесі підготовки майбутніх фахівців педагогічних спеціальностей. Від педагога очікують не лише досконалого володіння предметом викладання, але й мистецтвом акторської майстерності, педагогічної імпровізації.

Варто наголосити i на важливості експертної зовнішньої оцінки розроблених проєктів, що надає можливість відслідковувати їх ефективність, недоліки, пропозиції щодо вдосконалення й корекції. Характер зовнішньої оцінки значною мірою залежить від типу проєкту, його теми (змісту), умов проведення. Параметри зовнішньої оцінки проєкту: актуальність висунутих проблем і їх значущість для учасників; перспективність тематики дослідження; коректність використаних методів дослідження й обробки отриманих результатів; груповий характер виконання проєктів; активність кожного учасника проєкту відповідно до його індивідуальних можливостей; взаємодопомога й взаєморозуміння між учасниками проєкту; необхідна і достатня глибина занурення у проблему, використання знань з інших галузей; доказовість прийнятих рішень; уміння відповідати на запитання опонентів, лаконічність відповідей кожного члена групи; уміння аргументувати власні висновки; естетика оформлення результатів проєкту.
Вимоги до структурування проєкту: вибір актуальної теми проєкту, визначення його типу, кількості учасників, терміну проведення; передбачення можливих варіантів розв'язання проблем у межах визначеної тематики; активна участь у проєкті студентів за підтримкою викладача (запитання, ситуації, що сприяють визначенню проблеми); розподіл завдань по групах; обговорення можливих методів дослідження; пошук інформації, творчих рішень у процесі роботи над проєктом; самостійна робота учасників проєкту щодо вирішення індивідуальних чи групових дослідницьких, творчих задач; колективне обговорення, експертиза, оголошення результатів зовнішньої оцінки, формулювання висновків; захист проєктів.

Висновки. Отже, використання проєктних технологій у вищій школі розвиває пізнавальну сферу та особистісні якості студентів, перетворює викладача із носія готових знань на організатора творчої діяльності майбутніх учителів. Проєктні технології вчать студентів самостійно шукати шляхи вирішення різних проблем, що мають теоретичне і практичне значення. На особливу увагу заслуговують рольові та ігрові проєкти, що викликають інтерес у майбутніх учителів і можливість змагатися за отримання певних результатів. Новими і перспективними проєктами під час викладання педагогічних дисциплін стали телекомунікаційні, що передбачають використання новітньої техніки (інтерактивних дошок, відеопристроїв, інтернет-ресурсів). У науковій діяльності майбутніх учителів виправдовують себе дослідницькі проєкти, у тому числі й під час написання дипломних робіт.

\section{ЛITЕРАТУРА}

1. Педагогічна інноватика: термінологічний словник / авт. кол. за заг. ред. О.І. Шапран. Переяслав-Хмельницький (Київ. обл.) : Домбровська Я.М., 2019. 384 с.

2. Бем І., Шнайдер Й. Складові системи продуктивного навчання. Завуч. 2009. № 14. С. 16.

3. Пєхота О.М. Освітні технології : навч.-метод. посіб. Київ : «А.С.К.», 2001. 254 с.

4. Педагогічні технології в підготовці вчителів : навч. посіб. / за ред. І.Ф. Прокопенка ; М-во освіти і науки України, НАПН України, Харків. нац. пед. ун-т ім. Г.С. Сковороди / 3-те вид., допов. і перероб. Харків : ХНПУ ім. Г.С. Сковороди, 2018. 454 с.

5. Сучасні педагогічні технології у професійній підготовці вчителів : навч. посіб. / за ред. О.І. Шапран. Переяслав-Хмельницький : «Видавництво К С В», 2012. 280 с.

\section{REFERENCES}

1. Pedahohichna innovatyka: terminolohichnyi slovnyk [Pedagogical innovation: a terminological dictionary] / avt. kol. za zah. red.O. I. Shapran. Pereiaslav-Khmelnytskyi (Kyiv. obl.) : Dombrovska Ya. M., 2019. 384 s.

2. Bem I., Shnaider Y. (2009) Skladovi systemy produktyvnoho navchannia [Components of productive learning systems]. Zavuch. 2009. № 14. S. 16.

3. Piekhota O. M. (2001) Osvitni tekhnolohii [Educational technologies] : navch.-metod. posib. Kyiv : "A.S.K.", 2001. $254 \mathrm{~s}$

4. Pedahohichni tekhnolohii $\mathrm{v}$ pidhotovtsi vchyteliv [Pedagogical technologies in teacher training]: navch. posib. / [Prokopenko I. F. ta in.]; za red. I. F. Prokopenka; M-vo osvity i nauky Ukrainy, NAPN Ukrainy, Kharkiv. nats. ped. un-t im. H. S. Skovorody. [3-tie vyd., dopov. i pererob.]. Kharkiv : KhNPU im. H. S. Skovorody, 2018. $454 \mathrm{~s}$.

5. Suchasni pedahohichni tekhnolohii u profesiinii pidhotovtsi vchyteliv [Modern pedagogical technologies in teacher training]: navch. posib / za red. O. I. Shapran. Pereiaslav-Khmelnytskyi : "Vydavnytstvo K S V", 2012. 280. 